\title{
Sesame (Sesamum indicum L.) Growth and Yield as Influenced by Preemergence Herbicides
}

\author{
W. J. Grichar, ${ }^{1}$ P. A. Dotray, ${ }^{2}$ and D. R. Langham ${ }^{3}$ \\ ${ }^{1}$ Texas AgriLife Research, 3507 Hwy 59E, Beeville, TX 78102, USA \\ ${ }^{2}$ Texas AgriLife Research, 1102 E FM 1294, Lubbock, TX 79403, USA \\ ${ }^{3}$ Sesaco Corporation, San Antonio, TX 78217, USA \\ Correspondence should be addressed to W. J. Grichar, w-grichar@tamu.edu \\ Received 6 July 2011; Revised 23 August 2011; Accepted 24 August 2011 \\ Academic Editor: M. Ali Tabatabai
}

Copyright (C) 2012 W. J. Grichar et al. This is an open access article distributed under the Creative Commons Attribution License, which permits unrestricted use, distribution, and reproduction in any medium, provided the original work is properly cited.

\begin{abstract}
Studies were conducted during the 2007 and 2008 growing seasons under weed-free conditions in South Texas and the High Plains region of Texas to evaluate preemergence herbicides for sesame tolerance. No reduction in sesame stand was noted with any herbicide at south Texas location; however, at the High Plains location, linuron at the $2 \mathrm{X}$ rate reduced stand counts 28 days after treatment (DAT) in 2007 and diuron reduced sesame stand 147 DAT in 2008 when compared with the untreated check. At the $1 / 2 \mathrm{X}$ rate all herbicides exhibited minimal stunting while at the $1 \mathrm{X}$ rate stunting was variable and varied between locations. At the $2 \mathrm{X}$ rate, all herbicides caused sesame stunting compared to the untreated check. No herbicide, with the exception of linuron at the $2 \mathrm{X}$ rate in 2008 at the High Plains location, reduced sesame yield when compared with the untreated check. Although some herbicide treatments resulted in sesame stunting, this did not result in any yield reductions and this can be attributed to the ability of the sesame plant to compensate for injury and/or reduced stands.
\end{abstract}

\section{Introduction}

Sesame is one of the oldest crops known to humans. There are archeological remnants of sesame dating to 5,500 BC in the Harappa Valley in the Indian subcontinent [1]. Assyrian tablets from 4,300 B.C. in a British museum describe how, before the gods battled to restore order to the universe, they ate bread and drank sesame wine together [2]. Sesame was a major oilseed in the ancient world because of its ease of extraction, its great stability, and its drought resistance [1]. In India today, almost as in olden days, a farmer can take his crop to an expeller that consists of grinding mortar and pestle stones driven by a bullock. They can place the oil in a vessel, take it back to their home and have cooking oil for a year without the oil going rancid (S.S. Rajan, personal communication).

Sesame was introduced to the US from Africa was called beni/benne/benni. Betts [3] quotes letters from Thomas Jefferson that document his trials with sesame between 1808 and 1824. Jefferson stated that sesame "...is among the most valuable acquisitions our country has ever made. ...I do not believe before that there existed so perfect a substitute for olive oil." He talks about the rule of thumb that still exists today-that sesame will do well where cotton does well.

Sesame was produced in Texas on a limited scale during the 1950s and early 1960s, first in Northeast Texas and later shifting to the High Plains, where consistent yield increases resulted from irrigation and more favorable climate conditions $[4,5]$. The sesame was cut with a binder, hand shocked, and manually fed into a combine when dry. Due to a change in guest worker laws in the mid 1960s, the hand labor from Mexico became unavailable, and the sesame crop disappeared [6]. Sesame returned to Texas in 1987 and has spread to Oklahoma and Kansas with varieties that did not require binding and shocking. The sesame could be swathed into a windrow, allowed to dry, and then picked up with a pick-up attachment on a combine. Since that time, new varieties have been developed that can be left standing in the field to dry down and combined directly [7].

One of the most difficult problems in planting sesame is that the seeds are small and need to be placed precisely in the soil [7-9]. Seed cannot be too deep that the cotyledons 
never reach the surface, and yet they cannot be too shallow that the moisture around the seed is lost. Once the cotyledons emerge, they are small compared to other crops and do not grow as fast. This slow development is compounded by the nature of the drought resistance of sesame in that it will partition a large portion of photosynthetic resources to create more root mass to penetrate the soil as quickly as possible to reach moisture [7-9].

In the first 30 days, sesame plants reach about $28 \mathrm{~cm}$ in height and yet will double to $60 \mathrm{~cm}$ in 41 days, triple to $90 \mathrm{~cm}$ in 49 days, and quadruple to $120 \mathrm{~cm}$ in 58 days after emergence. At this point the sesame will begin to canopy. Depending on row spacing and phenotype, mechanization of sesame requires good weed control for 50 to 60 days after planting [7-9].

The presence of weeds can negatively influence sesame yield [4, 5, 10-13]. Kropff and Spitters [14] reported that the major factor influencing sesame yield loss in a competitive situation between the crop and weed is the ratio between the relative leaf area of the weed and the crop at the time of crop canopy closure. The effects of weeds on sesame establishment and growth have been well documented. Weeds can result in reductions of sesame yield up to $65 \%$ and sesame needs a critical weed-free period up to 50 days after planting $[4,5$, 10-12]. Under weedy conditions, a weed biomass of 1.3 to $6 \mathrm{X}$ that of sesame was reported 42 and 48 days after planting, respectively [15].

Mechanically harvested nondehiscent varieties present another problem that is not present in manual harvest which comprises $99 \%$ of all sesame harvested in the world [6]. If there are weeds in manual harvest, only the sesame plants are cut and placed in the shocks. However, in mechanical harvest, sesame and weeds are cut together. In Venezuela, a binder cuts the sesame and weeds together while they are still green, but this is not a big problem because the weeds dry down at the same time as the sesame (author's personal observation). The only concern is that a high population of weeds may delay combining, leaves of the weeds may envelop plants and trap moisture, or thicker stem weeds such as pigweed (Amaranthus spp.) will take longer to dry down $[6,7]$.

In direct combining, weeds can be a big problem because they add moisture to the combine bin. There are many cases where the sesame seeds are dry and weed seeds are not. Thick stems can add moisture, but the major problem is with weed seeds $[6,7]$. Since it is logistically difficult to scalp off the weed seeds at harvest, moisture from the weeds will transfer to sesame seeds. Sesame is $50 \%$ oil and needs to be harvested at $6 \%$ moisture or below in order to be effectively handled by trucks and in silos [9]. High moisture under these conditions can lead to heating and ruining of the seed. A second concern is that mechanically harvested sesame moves through a series of augers from the combine screen, to the combine bin, to the truck, to the silo, to the cleaning equipment, and within the cleaning process. Moist sesame can be damaged by this movement forming free fatty acids that leads to spoiling [6].

Since sesame seed is similar to the size of many weed seeds, problems may develop in processing $[7,9]$. In the use of oil, weed seeds within the sesame samples are not as critical unless they are toxic. However, a large percentage of sesame is used in edible markets that require $99.99 \%$ purity. There are seeds such as johnsongrass (Sorghum halepense (L.) Pers.) that would seemingly be easy to remove because of their size and shape; yet, Johnsongrass seed go through the round holes end first and are difficult to separate in gravity tables because they have a similar specific gravity to sesame [9]. In decortication of the seed for bakery products and tahini, the seed from lanceleaf sage (Salvia reflexa Hornem.) can cause a unique problem. When the lanceleaf sage seed is hydrated, the seed surface forms a gelatinous substance that will cause all the sesame seeds around it to stick and form balls. Kochia (Kochia scoparia (L.) Schrad.) and grass seeds are difficult to clean out of sesame. Any weed seed that is in a sesame sample in a large percentage is difficult to clean out no matter the size and specific gravity without having to slow down the processing or reprocessing $[6,7,9]$. In Japan, purity needs to be $100 \%$ since processors have to pay claims to customers that find anything other than pure sesame seeds (author's personal observation).

Sesame has mainly been grown in countries where abundant and inexpensive labor is available [2, 6, 7, 15]. However, the trend in agriculture around the world is towards mechanization [6]. Sesame has disappeared in Japan and parts of Mexico as the sesame-growing areas mechanized [6]. In Korea, sesame acres have continually decreased since 1987 as the labor migrates to the cities (C. Kang, personal communication). With weak seedling vigor, limited competitive ability, and a lack of cheap labor, the use of PRE herbicides are essential for commercial mechanized sesame production.

The authors have been screening preemergence (PRE) herbicides since 1991 [4, 11]. Pigweed spp. (Amaranthus spp.) and small-seeded annual grasses cause the greatest problems in sesame production. Since sesame-planted hectares may increase in portions of the southwestern USA, and since no PRE herbicides were registered for use on sesame in the USA at the time of this study, the objective of these studies was to identify preemergence herbicides that could be used to control weeds and provide crop safety during sesame establishment.

\section{Materials and Methods}

2.1. Research Sites. Field studies were conducted during the 2007 and 2008 growing seasons near Uvalde in South Texas sesame-growing region and near Lorenzo in Texas High Plains sesame-growing region to evaluate sesame response to PRE herbicides. Fields were selected that had low weed populations since the weed efficacy of each herbicide is already known and not the focus of these experiments. Soil type at Uvalde was a Winterhaven silty clay loam (fine-silty, carbonatic, hyperthermic Fluventic Ustochrepts) with less than $1.0 \%$ organic matter and $\mathrm{pH} 7.8$. Soil type at Lorenzo was a Amarillo sandy clay loam (fine-loamy, mixed, thermic Aridic Paleustalf) with $0.8 \%$ organic matter and $\mathrm{pH} 7.8$.

2.2. Herbicides and Application. A randomized completeblock experimental design was used and treatments were 
replicated three times. Treatments consisted of a factorial arrangement of four herbicide treatments and three rates $(1 / 2 \mathrm{X}, 1 \mathrm{X}$, and $2 \mathrm{X})$ with a nontreated comparison. Herbicides included diuron (Direx Herbicide, DuPont Crop Protection, Laurel Run Building, Chestnut Run Plaza, Wilmington, DE, USA) and linuron (Linex Herbicide, TKI NovaSource Crop Protection, 2255 44th St., Phoenix, AZ, USA) at $0.6(1 / 2 \mathrm{X}), 1.2(1 \mathrm{X})$, and $2.4(2 \mathrm{X}) \mathrm{kg}$ ai/ha, $S$-metolachlor (Dual Magnum Herbicide, Syngenta Crop Protection, Inc., Greensboro, NC, USA) at $0.7(1 / 2 \mathrm{X}), 1.4(1 \mathrm{X})$, and 2.8 (2X) $\mathrm{kg}$ ai/ha, and linuron plus diuron (Layby Pro Herbicide, DuPont Crop Protection, Laurel Run Building, Chestnut Run Plaza, Wilmington, DE, USA) at $0.3+0.3(1 / 2 \mathrm{X}), 0.6+0.6$ (1X), and $1.2+1.2(2 \mathrm{X}) \mathrm{kg}$ ai/ha. At Uvalde, PRE herbicides were applied $2 \mathrm{~d}$ after sesame planting in 2007 and $1 \mathrm{~d}$ after planting in 2008, while at Lorenzo herbicides were applied $1 \mathrm{~d}$ after sesame planting in 2007 and the same day as sesame planting in 2008.

Herbicides were applied in water using a $\mathrm{CO}_{2}$ pressurized backpack sprayer with either Teejet 11002 DG, or Turbotee 110015 flat fan spray tips (Teejet Spraying Systems Co., Wheaton, IL, USA) calibrated to deliver $190 \mathrm{~L} / \mathrm{ha}$ at $180 \mathrm{kPa}$ at Uvalde and Turbotee 110015 calibrated to deliver $140 \mathrm{~L} / \mathrm{ha}$ at $207 \mathrm{kPa}$ at Lorenzo.

Plot size was five-rows ( $76 \mathrm{~cm}$ apart) by $9.1 \mathrm{~m}$ at Uvalde and four rows $(101 \mathrm{~cm}$ apart) by $7.8 \mathrm{~m}$ at Lorenzo. Two rows were left untreated on the left side and one row was left untreated on the right side of the five row plot with the remaining two rows sprayed and the other rows were untreated and served as buffers.

2.3. Sesame Plantings, Observations, and Harvest. The sesame variety "S-32" was planted at both locations since it is the main variety used in all sesame growing areas of the USA [16]. Planting dates at the Uvalde location was June 2 in 2007 and May 30 in 2008 while at the Lubbock location, sesame was planted June 18 in 2007 and June 26 in 2008. Each sesame cultivar was seeded approximately $1.0 \mathrm{~cm}$ deep at $9 \mathrm{~kg} / \mathrm{ha}$ at both locations. Sesame injury (stunting) due to PRE herbicides was evaluated based on a scale of 0 (no stunting) to 100 (complete plant death). Observations were recorded approximately 4 and 8 wks after PRE herbicides were applied at Lorenzo in both years and Uvalde in 2007. Due to the lack of rainfall for the first $28 \mathrm{~d}$ after planting at Uvalde in 2008, no sesame stunting was noted.

Sesame stand counts were recorded 28 days after treatment (DAT) and at harvest, 127 to 134 DAT at Lorenzo and Uvalde in 2007. In 2008, stand counts were recorded at harvest only (147 DAT). When completely dry, sesame plants were counted in one meter of row of each 2 row plot. Plants in each plot were hand-cut, bagged, and threshed with a harvester to obtain sesame yield. Sesame yields were obtained at all locations except the Uvalde location in 2007 where glyphosate spray drift from an adjacent grain sorghum (Sorghum bicolor (L.) Moench) field approximately 8 wks after sesame was planted caused reduced sesame growth in two-thirds of the experimental area.
2.4. Data Analysis. Data for percentage of sesame stunting were transformed to the arcsine square root prior to analysis; however, nontransformed means are presented because arcsine transformation did not affect interpretation of the data. Data were subjected to analysis of variance (ANOVA) and analyzed using SAS PROC MIXED with locations and years designated as random effects in the model. A mixed model was chosen because the actual environments experienced at both locations in Texas where the experiments were conducted are unlikely to occur again in the future. Allowing the six environments to be random allows estimates of treatment responses to be made over a range of environments [17]. Treatment means were separated using Fisher's Protected LSD at $P \leq 0.05$. The untreated check was used for stand counts and yield comparison and a visual comparison for sesame stunting and was only included in stand and yield data analysis.

\section{Results}

3.1. Sesame Stand as Influenced by Preemergence Herbicides. A significant herbicide by rate interaction occurred at Lorenzo in 2007 when stand counts were recorded 28 DAT (Table 1); however, no other interactions were noted. In 2008 at Lorenzo, when rated 147 DAT, herbicide and rate were significant (Table 2).

When stand count determinations were done earlyseason and at harvest, sesame stands were reduced by time. Although this reduction has been known intuitively through observations in various fields, this is the first time that the reduction has been verified by field counts. Also, there was more effect on sesame stand from herbicides at Lorenzo than Uvalde. At Lorenzo in 2007, when rated 28 DAT, diuron and linuron showed a reduction in stand as herbicide rate increased while $S$-metolachlor and the premix of linuron + diuron did not show a rate response (Table 1). Linuron resulted in the greatest reduction in stand with over a $50 \%$ stand reduction as the rate increased from the $1 / 2 \mathrm{X}$ to $2 \mathrm{X}$ rate. In 2008 at Lorenzo, when rated 147 DAT, diuron and linuron + diuron reduced sesame stand when compared with the untreated check (Table 2). None of the other herbicides reduced sesame stand when compared with the untreated check. The $2 \mathrm{X}$ herbicide rate reduced sesame stand when compared with the untreated or the $1 / 2 \mathrm{X}$ rate (Table 2 ). No differences in stands were noted at Uvalde in either year (Table 1).

Establishing an adequate stand is the biggest challenge for a sesame grower. In numerous yield analysis, Langham [8] found little differences in sesame yield from populations of 10 to 26 plants $/ \mathrm{m}^{2}$ with sesame cultivars that adjust to the population; that is, produce more branches (and therefore more capsules) under low populations. The most common row spacings in the USA are 38,75 , and $100 \mathrm{~cm}$; therefore, the populations of 10 to 26 plants $/ \mathrm{m}^{2}$ translate to 4 to 10 plants, 8 to 20 plants, and 10 to 26 plants per linear $\mathrm{m}$, respectively. The seeds can emerge from 0.7 to $1.6 \mathrm{~cm}$ depth and have emerged from as deep as $2.4 \mathrm{~cm}$ [8]. The recommendation is to plant 80 to $115 \mathrm{seed} / \mathrm{m}$ and a grower can expect 35 to 60 seedlings to emerge [9]. The higher the number 
TABLE 1: Sesame stand response to preemergence herbicides at two locations in Texas.

\begin{tabular}{|c|c|c|c|c|c|c|}
\hline \multirow{3}{*}{ Treatment } & \multicolumn{3}{|c|}{$\begin{array}{c}\text { Lorenzo } \\
2007\end{array}$} & \multicolumn{3}{|c|}{ Uvalde } \\
\hline & Rate & $28 \mathrm{DAT}^{\mathrm{a}}$ & 134 DAT & $28 \mathrm{DAT}$ & $127 \mathrm{DAT}$ & 194 DAT \\
\hline & $\mathrm{kg}$ ai/ha & & & Plants/m & & \\
\hline Untreated & - & 35 & 21 & 40 & 30 & 43 \\
\hline Diuron $(1 / 2 X)$ & 0.6 & 41 & 22 & 41 & 34 & 42 \\
\hline$(1 \mathrm{X})$ & 1.2 & 31 & 20 & 48 & 31 & 40 \\
\hline$(2 \mathrm{X})$ & 2.4 & 25 & 17 & 39 & 22 & 44 \\
\hline Linuron $(1 / 2 \mathrm{X})$ & 0.6 & 36 & 22 & 40 & 31 & 40 \\
\hline$(1 \mathrm{X})$ & 1.2 & 27 & 18 & 49 & 28 & 37 \\
\hline$(2 \mathrm{X})$ & 2.4 & 17 & 21 & 44 & 29 & 39 \\
\hline$S$-metolachlor $(1 / 2 \mathrm{X})$ & 0.7 & 32 & 22 & 64 & 26 & 44 \\
\hline$(1 \mathrm{X})$ & 1.4 & 25 & 16 & 37 & 27 & 47 \\
\hline$(2 \mathrm{X})$ & 2.8 & 32 & 19 & 41 & 29 & 45 \\
\hline Linuron + diuron $(1 / 2 \mathrm{X})$ & $0.3+0.3$ & 40 & 22 & 46 & 33 & 46 \\
\hline$(1 \mathrm{X})$ & $0.6+0.6$ & 31 & 21 & 48 & 27 & 43 \\
\hline$(2 \mathrm{X})$ & $1.2+1.2$ & 28 & 20 & 43 & 32 & 43 \\
\hline LSD (0.05) & & 15 & NS & NS & NS & NS \\
\hline
\end{tabular}

${ }^{a}$ DAT: days after treatment; NS: not significant at $5 \%$ level of significance.

TABle 2: Sesame stand response to preemergence herbicides and herbicide rate at Lorenzo in $2008^{\mathrm{a}}$.

\begin{tabular}{lc}
\hline Herbicide & Plants/m \\
\hline Untreated & 20 \\
Diuron & 16 \\
Linuron & 19 \\
S-metolachlor & 20 \\
Linuron + diuron & 18 \\
LSD (0.05) & 2 \\
\hline Rate & \\
0 & 20 \\
$1 / 2 X$ & 22 \\
$1 X$ & 18 \\
$2 X$ & 15 \\
LSD (0.05) & 5 \\
\hline
\end{tabular}

a Plant counts taken 147 days after herbicide treatment.

of seeds planted per $\mathrm{m}$, the greater the percentage that will emerge since adjoining seeds help push through the soil. The recommendation is greater (100 to $130 \mathrm{seed} / \mathrm{m})$ when there are possible herbicide residues, planting depth is greater, soil compaction is present, the soil is cloddy/trashy, under cooler temperatures, in marginal moisture, when soils change within a field, or in fields with hills and low spots [9].

Sesame is bred to adjust to low and high populations [9]. Under low populations, sesame plants will produce more branching and under high populations, the plants will selfthin under most conditions. Seedlings that emerge $6 \mathrm{~h}$ ahead of neighboring seedlings (generally planted shallower, using less stored resources to emerge) will have larger cotyledons and those that emerge early will also start growing faster and soon the leaves will cover the later emerged seedlings. This process continues throughout the growing cycle resulting in dominant and minor plants. At some point, minor plants will die out. The earlier the self-thinning the better, since minor plants use moisture and nutrients that could be used by the dominant plants [9]. It is better to have a high population than a lower population since the latter can lead to plant stand gaps. Branching can only compensate for gaps of about $30 \mathrm{~cm}$. Wider gaps not only lead to lower yields, but also let light through the canopy to encourage late weed emergence and growth.

3.2. Sesame Stunting as Affected by Herbicides. There was a herbicide by rate interaction for sesame stunting at Lorenzo in 2007 and Uvalde in 2007 when rated 28 DAT (Table 3). At the 53 DAT rating at Uvalde in 2007, there was a herbicide and rate effect; however, at both ratings at Lorenzo in 2008 there was only a rate effect (Table 4).

As time progressed, stunting was reduced. At Lorenzo in 2007 when rated $28 \mathrm{DAT}$, linuron at $2.4 \mathrm{~kg} / \mathrm{ha}$ (2X) caused the greatest stunting $(58 \%)$, while diuron, $S$-metolachlor, and linuron + diuron at the $2 \mathrm{X}$ rate resulted in stunting that ranged from 18 to $27 \%$ (Table 3 ). No stunting was noted with the $1 / 2 \mathrm{X}$ rate of any herbicide; however, the $1 \mathrm{X}$ and $2 \mathrm{X}$ rates of all herbicides caused stunting when compared with the untreated check. At the 55 DAT rating, diuron at $2.4 \mathrm{~kg} / \mathrm{ha}(2 \mathrm{X})$, linuron at $1.2(1 \mathrm{X})$ and $2.4 \mathrm{~kg} / \mathrm{ha}(2 \mathrm{X})$, $S$-metolachlor at all rates, and linuron + diuron at $1.2+$ $1.2 \mathrm{~kg} / \mathrm{ha}(2 \mathrm{X})$ resulted in stunting greater than the untreated check. At Uvalde when rated 28 DAT, the high rates of all herbicides with the exception of linuron + diuron resulted in sesame stunting greater than the untreated check. At the 53 DAT rating, diuron and $S$-metolachlor caused the greatest stunting while the $1 \mathrm{X}$ and $2 \mathrm{X}$ rates caused greater stunting than the $1 / 2 \mathrm{X}$ rate (Table 4 ). 
TABLE 3: Sesame stunting as influenced by preemergence herbicides at two locations in Texas.

\begin{tabular}{|c|c|c|c|c|}
\hline \multirow{3}{*}{ Treatment } & \multirow{3}{*}{$\begin{array}{c}\text { Rate } \\
\text { kg ai/ha }\end{array}$} & \multicolumn{2}{|c|}{$\begin{array}{c}\text { Lorenzo } \\
2007\end{array}$} & \multirow{3}{*}{$\begin{array}{c}\text { Uvalde } \\
2007 \\
28 \text { DAT }\end{array}$} \\
\hline & & $28 \mathrm{DAT}^{\mathrm{a}}$ & 55 DAT & \\
\hline & & & Percent & \\
\hline Untreated & - & 0 & 0 & 0 \\
\hline Diuron $(1 / 2 \mathrm{X})$ & 0.6 & 1 & 0 & 10 \\
\hline$(1 \mathrm{X})$ & 1.2 & 13 & 5 & 12 \\
\hline$(2 \mathrm{X})$ & 2.4 & 25 & 9 & 63 \\
\hline Linuron $(1 / 2 \mathrm{X})$ & 0.6 & 3 & 0 & 3 \\
\hline$(1 \mathrm{X})$ & 1.2 & 18 & 7 & 7 \\
\hline$(2 \mathrm{X})$ & 2.4 & 58 & 20 & 17 \\
\hline$S$-metolachlor $(1 / 2 \mathrm{X})$ & 0.7 & 7 & 10 & 3 \\
\hline$(1 \mathrm{X})$ & 1.4 & 20 & 12 & 10 \\
\hline$(2 \mathrm{X})$ & 2.8 & 18 & 12 & 33 \\
\hline Linuron + diuron $(1 / 2 \mathrm{X})$ & $0.3+0.3$ & 2 & 2 & 0 \\
\hline$(1 \mathrm{X})$ & $0.6+0.6$ & 10 & 5 & 17 \\
\hline$(2 \mathrm{X})$ & $1.2+1.2$ & 27 & 13 & 10 \\
\hline $\operatorname{LSD}(0.05)$ & & 9 & 7 & 17 \\
\hline
\end{tabular}

${ }^{\mathrm{a} D A T}$ : days after treatment.

TABLE 4: Sesame stunting as influenced by preemergence herbicides and herbicide rate at Lorenzo in 2008 and Uvalde in 2007.

\begin{tabular}{lccc}
\hline & \multicolumn{2}{c}{ Lorenzo } & Uvalde \\
Herbicide & $28 \mathrm{DAT}^{\mathrm{a}}$ & $\begin{array}{c}56 \text { DAT } \\
\text { Plants/m }\end{array}$ & 53 DAT \\
\hline Diuron & & 9 & 18 \\
Linuron & 13 & 5 & 5 \\
S-metolachlor & 9 & 4 & 11 \\
Linuron + diuron & 7 & 7 & 5 \\
LSD (0.05) & 9 & $\mathrm{NS}$ & 8 \\
\hline Rate & $\mathrm{NS}$ & & \\
1/2X & & 0 & 3 \\
1X & 0 & 2 & 10 \\
2X & 3 & 17 & 16 \\
LSD (0.05) & 25 & 7 & 7 \\
\hline
\end{tabular}

${ }^{a}$ DAT: days after treatment; NS: not significant at the 5\% level of significance.

No sesame stunting with any herbicides was noted in 2008 at Uvalde (data not shown). Rainfall was less than $1.0 \mathrm{~mm}$ during the first $4 \mathrm{wk}$ after planting. Supplemental irrigation (furrow) was applied but only enough to provide moisture for minimal sesame early-season growth. Rainfall or irrigation is required to move the herbicide into either the shoot or root zone before uptake can occur $[4,11,18]$. Also, herbicides that diffuse primarily in soil air are not active in extremely dry soil. The lack of activity is likely due to almost complete adsorption of the herbicide in soils with moisture contents slightly below the permanent-wilting point [18].

3.3. Sesame Yield as Influenced by Herbicides. There was a herbicide by rate interaction for sesame yield at Lorenzo
TABLE 5: Sesame yield response to preemergence herbicides at two locations in Texas.

\begin{tabular}{|c|c|c|c|c|}
\hline \multirow[b]{2}{*}{ Treatment } & \multirow[b]{2}{*}{$\begin{array}{c}\text { Rate } \\
\mathrm{kg} \text { ai/ha }\end{array}$} & \multicolumn{2}{|c|}{ Lorenzo } & \multirow{2}{*}{$\begin{array}{c}\text { Uvalde } \\
2008\end{array}$} \\
\hline & & 2007 & $\begin{array}{l}2008 \\
\mathrm{~kg} / \mathrm{ha}\end{array}$ & \\
\hline Untreated & - & 1224 & 763 & 1233 \\
\hline Diuron $(1 / 2 \mathrm{X})$ & 0.6 & 1417 & 835 & 1127 \\
\hline$(1 \mathrm{X})$ & 1.2 & 1350 & 751 & 1211 \\
\hline$(2 \mathrm{X})$ & 2.4 & 1215 & 742 & 1105 \\
\hline Linuron $(1 / 2 \mathrm{X})$ & 0.6 & 1280 & 829 & 1199 \\
\hline$(1 \mathrm{X})$ & 1.2 & 1278 & 879 & 1300 \\
\hline$(2 \mathrm{X})$ & 2.4 & 1267 & 625 & 1289 \\
\hline S-metolachlor $(1 / 2 \mathrm{X})$ & 0.7 & 1168 & 773 & 1233 \\
\hline$(1 \mathrm{X})$ & 1.4 & 1138 & 834 & 1161 \\
\hline$(2 \mathrm{X})$ & 2.8 & 1185 & 888 & 1237 \\
\hline Linuron + diuron $(1 / 2 \mathrm{X})$ & $0.3+0.3$ & 1203 & 790 & 1199 \\
\hline$(1 \mathrm{X})$ & $0.6+0.6$ & 1327 & 767 & 1121 \\
\hline$(2 \mathrm{X})$ & $1.2+1.2$ & 1374 & 781 & 1239 \\
\hline LSD (0.05) & & $N^{a}{ }^{a}$ & 140 & NS \\
\hline
\end{tabular}

${ }^{a}$ NS: not significant at the $5 \%$ level of significance.

in 2008; however, there were no differences in yield at Lorenzo in 2007 or Uvalde in 2008 (Table 5). Although stunting was noted with higher herbicide rates, the treated and untreated plants started to flower at approximately the same time and produced a similar number of capsules. A lack of yield differences among herbicide treatments that resulted in sesame injury may be attributed to the ability of the sesame plant to compensate for injury and/or reduced stands. Sesame can produce excellent yields with only 3 to 6 plants/m $[4,5,8,9,11]$. At Lorenzo in 2008, linuron at $2.4 \mathrm{~kg} / \mathrm{ha}(2 \mathrm{X})$ resulted in a yield reduction when compared with linuron at 0.6 and $1.2 \mathrm{~kg} / \mathrm{ha}$ (Table 5 ).

\section{Discussion}

4.1. Previous Herbicide Research in Sesame. A review of the literature revealed limited research and inconsistencies in phytotoxicity of PRE herbicides on sesame. Hussien et al. [12] compared metolachlor at $1.2 \mathrm{~kg} / \mathrm{ha}$ and trifluralin at $1.6 \mathrm{~kg} / \mathrm{ha}$ with weed-free and weedy checks and found that metolachlor and trifluralin increased sesame yield by $45 \%$ when compared with the unweeded check. In previous studies in south Texas, under weedy conditions, metolachlor at 0.6 to $3.4 \mathrm{~kg} / \mathrm{ha}$ did not reduce sesame height or yield when compared with the untreated check [5]. In another study with $S$-metolachlor, no injury or sesame stand reduction was noted with $S$-metolachlor at $1.4 \mathrm{~kg} / \mathrm{ha}$ in south Texas; however, at the Texas High Plains location, S-metolachlor reduced sesame plant stands and caused sesame stunting when compared with the untreated check in one of two years $[7,11]$. Sesame yields were not taken at the High Plains location but $S$-metolachlor did not reduce sesame yield when compared with the untreated check at the south Texas location [11]. In Egypt, metolachlor and a premix of metolachlor 
and metobromuron were tested at 1.2 and $1.8 \mathrm{~kg} / \mathrm{ha}$. The premix of metolachlor and metobromuron provided good broadleaf weed control while both metolachlor alone and the premix provided good annual grass control [12]. In Nicaragua, metolachlor (1.5 and $2.2 \mathrm{~kg} / \mathrm{ha}$ ) provided good grass control, did not damage the sesame, and doubled the yield of the untreated check [7]. In Australia, it was reported that metolachlor adequately controlled weeds but caused unacceptable crop injury [7]. Despite that report, farmers use metolachlor for commercial sesame fields (M. Bennett, L. Serafin, and P. O'Shanesy, personal communication). $S$-metolachlor injury to sesame also has been noted in Oklahoma (Case Medlin, personal communication).

In Venezuela, diuron at 0.6 and $1.2 \mathrm{~kg} / \mathrm{h}$ a reduced yields, but the yields would have been much lower without weed control [7]. In the USA in one year, diuron at 0.8 and $1.6 \mathrm{~kg} / \mathrm{ha}$ provided adequate weed control without apparent crop injury whereas in another year there was chlorosis and stand reductions [19]. Further work in Venezuela showed that diuron provided reasonable control of weeds with no significant reduction in yield [7]. In Sri Lanka, diuron at 0.6 and $0.8 \mathrm{~kg} / \mathrm{ha}$ gave effective control of weeds with no significant reduction in yield [7]. In Ethiopia, diuron caused serious crop damage in both irrigated and rainfed trials [20]. In Egypt, diuron at $1.0 \mathrm{~kg} / \mathrm{ha}$ was tested alone and in tank mixtures with pendimethalin with the best results from the tank mixtures which controlled both grass and broadleaf weeds and resulted in higher yields [13]. In Brazil, diuron at $1 \mathrm{~kg} / \mathrm{ha}$ enhanced sesame seed production [10]. Also in Brazil, diuron mixtures $(0.75,1.0$, and $1.25 \mathrm{~kg} / \mathrm{ha})$ with pendimethalin and alachlor showed significant greater phytotoxicity with the highest dose. However, there was no significant difference in the height of the first fruiting branch, the number of capsules per plant, and the yield between herbicides.

Limited information is available on linuron use in sesame. Santelman et al. [21] found slight phytotoxicity and a reduction in sesame yield with linuron at $2.24 \mathrm{~kg} / \mathrm{ha}$. Diuron, linuron, the premix of diuron plus linuron, and $S$-metolachlor at $1 / 2 \mathrm{X}$ rate exhibited excellent sesame tolerance; however, when the rate was increased to $1 \mathrm{X}$ rate, linuron, and $S$-metolachlor resulted in the least sesame stunting. $S$-metolachlor controls many problem weeds found in sesame including pigweed (Amaranthus spp.), yellow nutsedge (Cyperus esculentus L.), and small seeded annual grasses including crabgrass spp. (Digitaria app.) but not Texas panicum (Panicum texanum L.) [22]. Control of morningglory species (Ipomoea spp.) can be erratic with metolachlor [22]; therefore, linuron would provide control of this and other weeds (author's personal observations).

\section{Acknowledgments}

This paper was supported by Sesaco Corporation. The authors thank Kevin Brewer, Dwayne Drozd, Lyndell Gilbert, Terry Wiemers, and Bill Klesel for helping in plot maintenance.

\section{References}

[1] D. Bedigian and J. R. Harlan, "Evidence for cultivation of sesame in the ancient world," Economic Botany, vol. 40, no. 2, pp. 137-154, 1986.

[2] E. A. Weiss, Castor, Sesame, and Safflower, Leonard Hill Books, London, UK, 1971.

[3] E. M. Betts, Thomas Jefferson's Garden Book (1766-1824), Thomas Jefferson Memorial Foundation, Inc, Charlottesville, VA, USA, 1999.

[4] W. J. Grichar, D. C. Sestak, K. D. Brewer, B. A. Besler, C. R. Stichler, and D. T. Smith, "Sesame (Sesamum indicum L.) tolerance and weed control with soil-applied herbicides," Crop Protection, vol. 20, no. 5, pp. 389-394, 2001.

[5] W. J. Grichar, D. C. Sestak, K. D. Brewer, B. A. Besler, C. R. Stichler, and D. T. Smith, "Sesame (Sesamum indicum L.) tolerance with various postemergence herbicides," Crop Protection, vol. 20, no. 8, pp. 685-689, 2001.

[6] D. R. Langham and T. Weimers, "Progress in mechanizing sesame in the US through breeding," in Trends in New Crops and New Uses, J. Janick and A. Whipkey, Eds., pp. 157-173, ASHS Press, Alexandria, VA, USA, 2002.

[7] D. R. Langham, W. J. Grichar, and P. A. Dotray, "Review of preemergence herbicide research on sesame," 2007, http://www.sesamegrowers.org/.

[8] D. R. Langham, "Phenology of sesame," in Issues in New crops and New Uses, J. Janick and A. Whipkey, Eds., pp. 144-182, ASHS Press, Alexandria, VA, USA, 2007.

[9] D. R. Langham, Growth and Development of Sesame, Sesaco Corporation, 2008.

[10] N. E. Beltrao, D. J. Vieira, L. B. Nobrega, and J. W. Santos, "Effects of fertilizers, cultivar and weed control in sesame," Pesquisa Agropecuaria Brasilieira, vol. 26, pp. 605-611, 1991.

[11] W. J. Grichar, P. A. Dotray, and D. Ray Langham, "Sesame (Sesamum indicum L.) response to preemergence herbicides," Crop Protection, vol. 28, no. 11, pp. 928-933, 2009.

[12] M. A. Hussien, A. H. El-Hatlab, M. S. Abd-El Raouf, S. A. Shaban, and M. H. El-Deek, "Effect of soil herbicides on weeds, yield and quality of sesame, Sesamum indicum L. Z. Acker," Pflanzenbou, vol. 152, pp. 173-185, 1983.

[13] A. F. Ibrahim, H. R. El Wekil, Z. R. Yehia, and S. A. Shaban, "Effect of some weed control treatments on sesame (Sesamum indicum L.) and associated weeds," Journal of Agronomy and Crop Science, vol. 160, pp. 319-324, 1988.

[14] M. J. Kropff and C. J. T. Spitters, "A simple model of crop loss by weed competition from early observations on relative leaf area of the weeds," Weed Research, vol. 31, no. 2, pp. 97-105, 1991.

[15] U. C. Upadhyay, "Weed management in oilseed crops," in Oilseed Production Constraints and Opportunities, H. C. Srivastava, S. Bhaskaran, B. Vatsya, and K. K. G. Menon, Eds., pp. 491-499, Oxford and IBH Publishing Company, New Delhi, India, 1985.

[16] D. R. Langham, J. Riney, G. Smith, T. Wiemers, D. Pepper, and T. Speed, "Sesame Producers Guide," 2011, http://sesaco.net/.

[17] S. G. Carmer, W. E. Nyquist, and W. M. Walker, "Least significant differences for combined analysis of experiments with two or three-factor treatment designs," Agronomy Journal, vol. 81, pp. 665-672, 1989.

[18] A. F. Wiese and D. T. Smith, "Herbicidal activity as affected by soil incorporation and rainfall," Weed Science, vol. 18, pp. 515-517, 1970.

[19] T. W. Culp and G. G. McWhorter, "Annual report of cooperative industrial crops and weed investigations, 1959," in Crops 
Research Division, ARS, USDA, Stoneville, MS, USA, 1959.

[20] J. E. Moore, "Evaluation of herbicides in irrigated and rain grown sesame in the lowlands of Ethiopia," in Proceedings of the 5th East African Weed Control Conference, vol. 5, pp. 108130, Nairobi, Kenya, 1974.

[21] P. W. Santelman, W. C. Elder, and R. S. Murlock, "The effect of several preemergence herbicides on guar, cowpeas, mungbeans, and sesame," Proceedings of the Southern Weed Science Society, vol. 16, p. 83, 1963.

[22] J. W. Wilcut, A. C. York, W. J. Grichar, and G. R. Wehtje, "The biology and management of weeds in peanut," in Advances in Peanut Science, H. E. Pattee and H. T. Stalker, Eds., pp. 207-244, American Peanut Research and Education Society, Stillwater, OK, USA, 1995. 


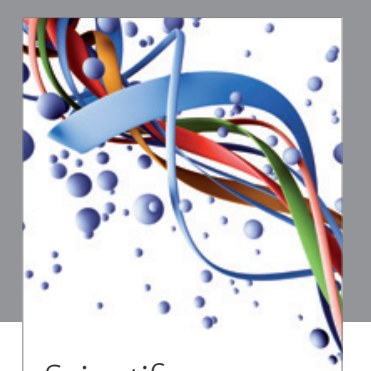

Scientifica
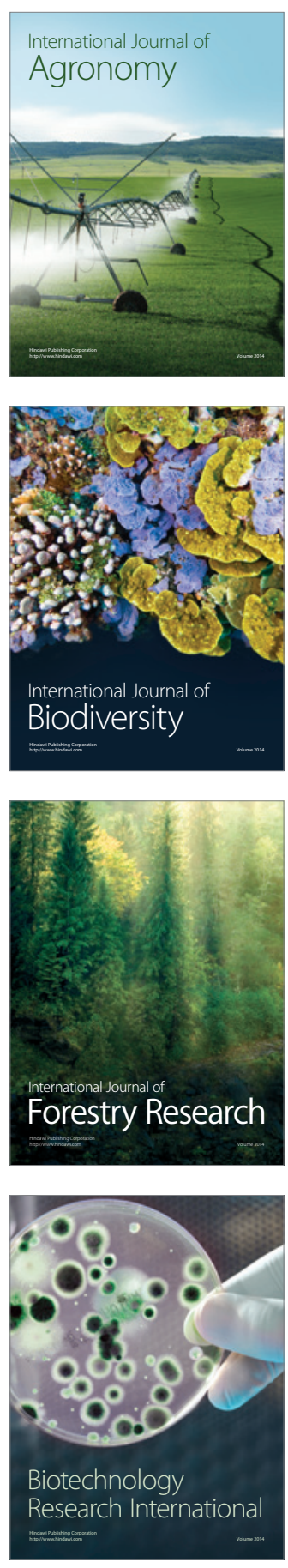
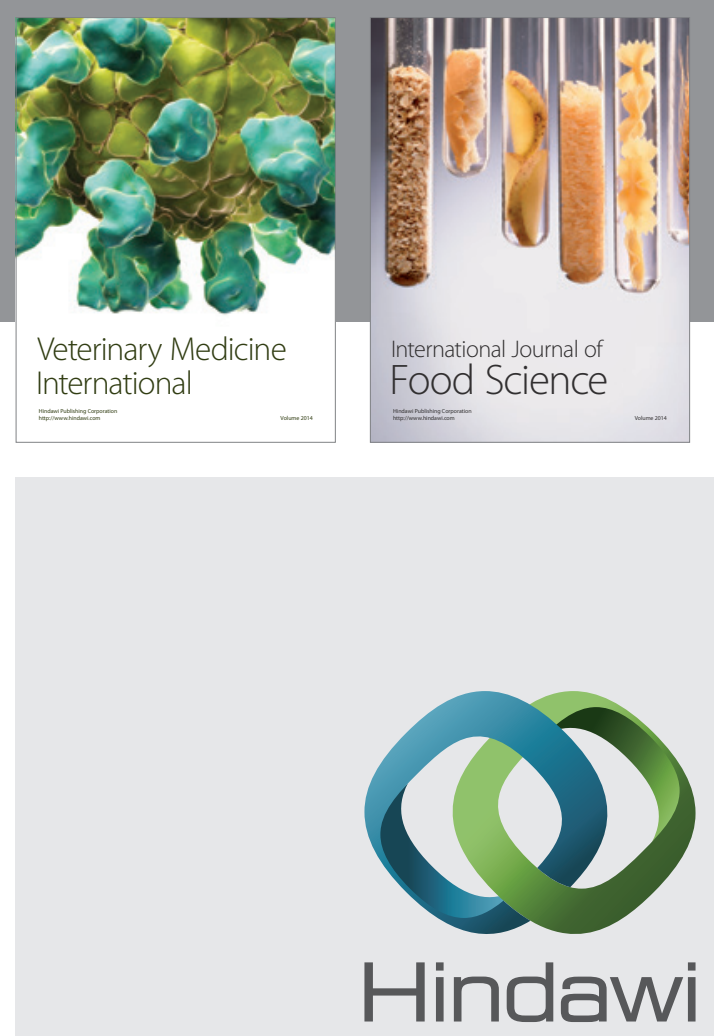

Submit your manuscripts at

http://www.hindawi.com
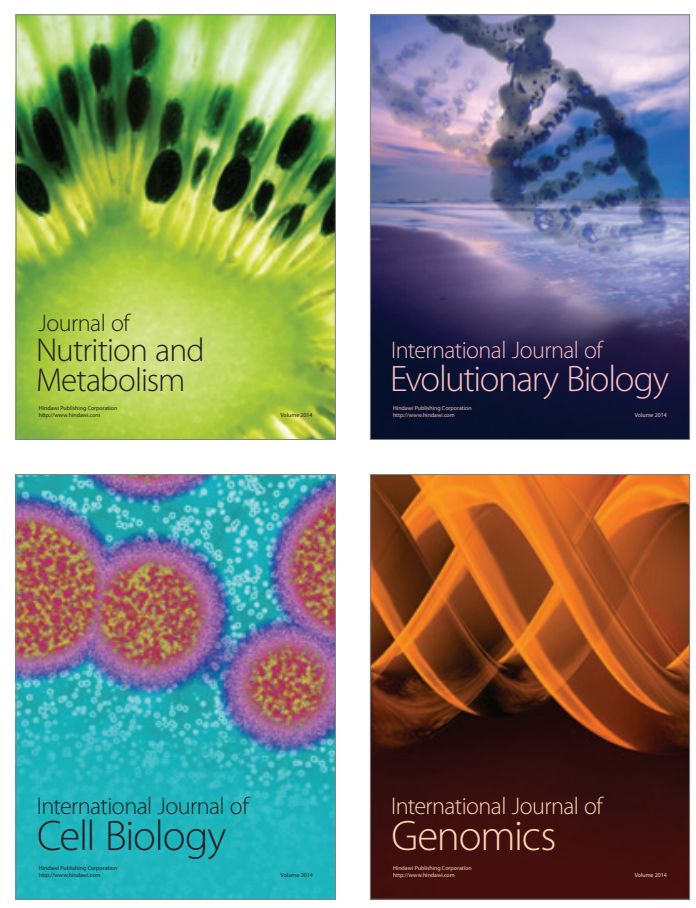
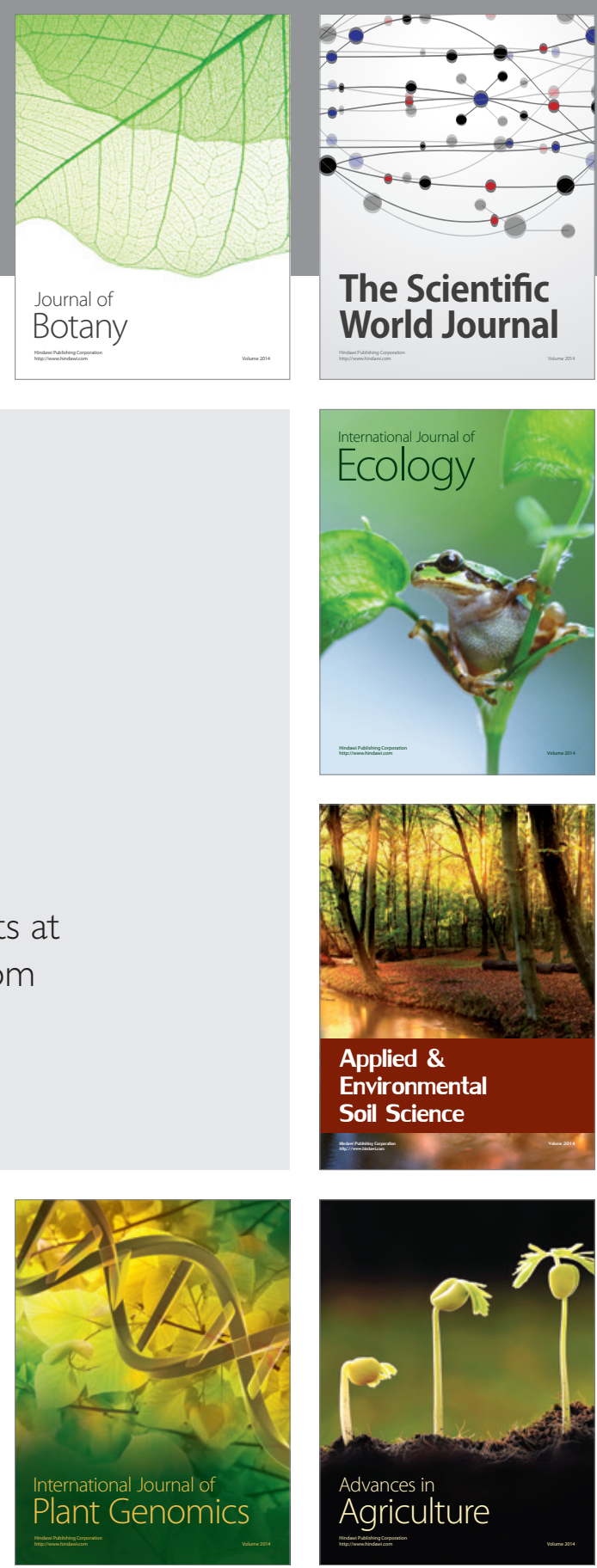

The Scientific World Journal
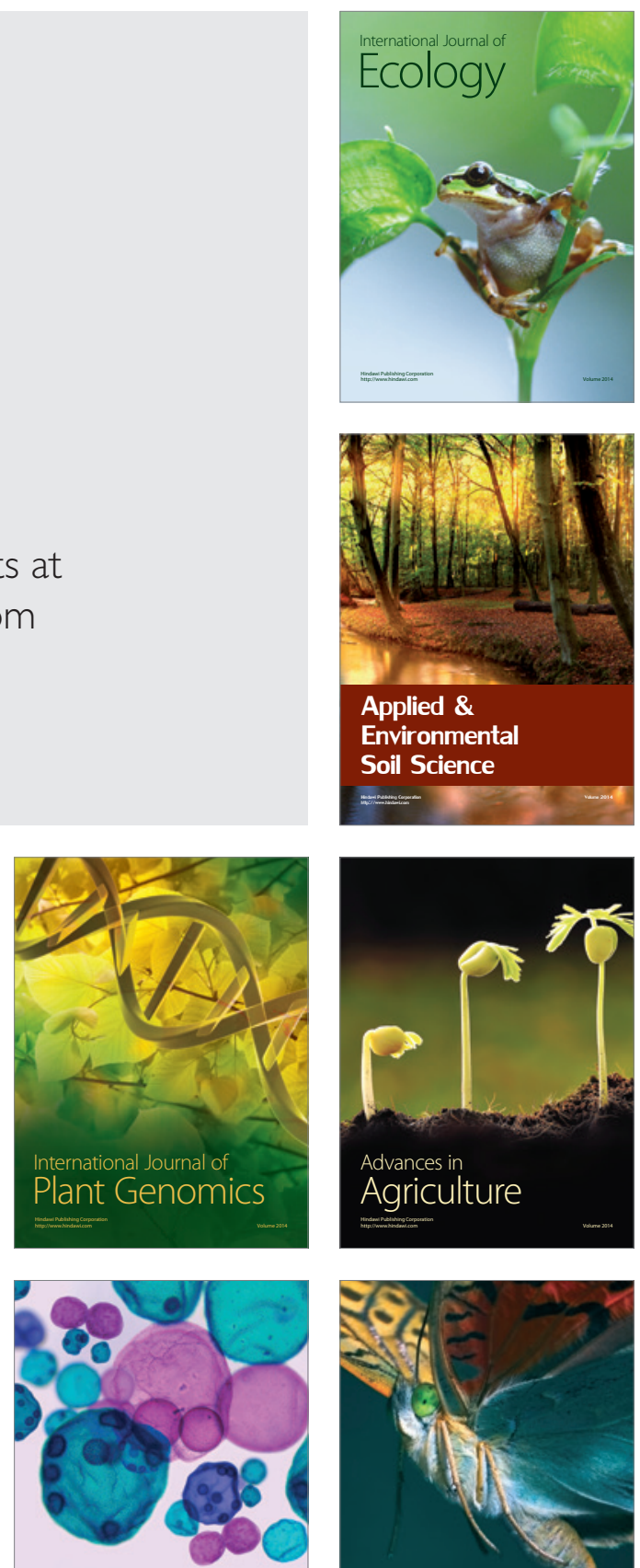

International Journal of Microbiology

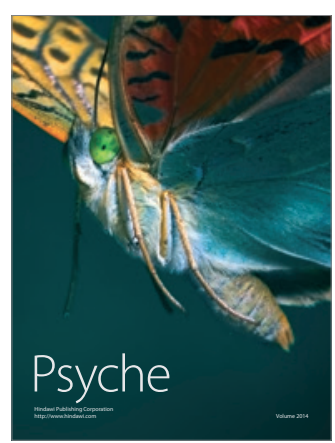

